\title{
Status of Health Promotion Established after the Family Health Strategy
}

\section{Vanessa Dayanny de Medeiros¹, Jovanka Bittencourt Leite de Carvalho', Gracimary Alves Teixeira², Flávio César Bezerra da Silva ${ }^{1}$}

\author{
${ }^{1}$ School of Health, The Federal University of Rio Grande do Norte, Natal, Rio Grande do Norte, Brazil \\ ${ }^{2}$ The Federal University of Rio Grande do Norte Program, Natal, Rio Grande do Norte, Brazil \\ Email: gracimaralves@yahoo.com.br
}

How to cite this paper: de Medeiros, V.D., de Carvalho, J.B.L., Teixeira, G.A. and da Silva, F.C.B. (2016) Status of Health Promotion Established after the Family Health Strategy. Open Journal of Nursing, 6, 10641074.

http://dx.doi.org/10.4236/ojn.2016.612101

Received: July 4, 2016

Accepted: December 27, 2016

Published: December 30, 2016

Copyright $\odot 2016$ by authors and Scientific Research Publishing Inc. This work is licensed under the Creative Commons Attribution International License (CC BY 4.0).

http://creativecommons.org/licenses/by/4.0/

\begin{abstract}
Objective: To summarize the scientific knowledge concerning the promotion of health after establishing the Family Health Strategy. Method: This is an integrative review conducted in databases: LILACS, MEDLINE/PubMed, SciELO and Cochrane, using following key words: Family Health Strategy; Health Promotion and Health Personnel. Results: After the criteria established 23 articles were selected, identifying strengths, weaknesses and challenges of health promotion after establishing the Family Health Strategy. Conclusion: Despite the effectiveness of health promotion practices in many health units of the family still persist the curative care model.
\end{abstract}

\section{Keywords}

Family Health Program, Health Promotion, Health Personnel

\section{Introduction}

According to the World Organization of Health (WHO), health concerns "the complete physical well-being, mental and social and not merely the absence of diseases or injuries" [1]. This concept has instigated reformulation of the dressing-privatizing clinical model focused on care of hospital central for a model with integral actions in the care of health [2].

The 1st International Conference on Health Promotion took place in November 1986 and it was considered a milestone in the field of health promotion, as well as the Ottawa Charter. In this context, health promotion was defined as the community empowerment process to act on improving the quality of life and health of the assisted population. However, for this, the participation of individuals in control of this process is necessary by: identifying their aspirations, satisfying their needs and modifying favorably 
the environment. In this direction it is necessary to earmark approach to social and personal resources as well as to physical capacities because health is more than a healthy lifestyle in an attempt to obtain a global welfare [3] [4].

In this sense, the implementation of Health Promotion has brought changes in the health area, and the absence of disease now has prerequisites. Thus, in the 90s, Law No. 8080, in its Article 3 specifies the determinants and conditioning factors to health: "Food, shelter, basic sanitation environment, labor, income, education, transport, leisure and access to essential goods and services" [4]. With that it has been the goal that people reach their highest health potential, changing habits, lifestyle and better quality of life [3] [5].

Moreover, Art 196 of the Constitution of 1988 states: "Health is a right of all and duty of the State and it is ensured through social and economic policies in order to reducing the risk of disease and other health problems. Added to this it is guaranteed by the State universal and equal access to actions and services for its promotion, protection and recovery" [4].

Thus, the current legislation proclaims that health promotion policies are structured on the basis of territory with the intersectoral participation. In addition it is also important to plan the health surveillance, and primary care, with funding by the three levels of management [6].

The current Family Health Strategy (FHT) was established in 1996 when the Brazilian Ministry of Health began to reformulate the concept of the Family Health Program (FHP). Thus, FHP worked with the idea of "verticality and transience" and the FHT introduced a strategy considering the reorganization of health services provided by Basic Care. The FHT innovates the assistance from the perspective of that people have prevention, promotion, and continuous, humane and good quality care [7].

In this way, the current actions in the FHS are performed by the team of health professionals consisting of at least: a family doctor or a generalist, a nurse, a nursing assistant and Community Health Agents (CHA). All these professionals work from a delimitation of territory where there is a construction of "intra- and extra-family relationships" and improvement of living conditions resulting from a better understanding of the health-disease process [8].

Thus, as the policies established in the FHS are actions focused on health promotion, the guiding question for this study is: what is the situation of health promotion established after the FHT assistance model?

In that way, the theme was thought because of the importance of Health Promotion contained in the FHT and what is established for the health of the family. In this sense, the objective is to synthesize scientific knowledge about the health promotion after fixing the FHS assistance model.

\section{Method}

This is an integrative review, in which previous studies are selected from the inclusion criteria and analyzed in relation to the objectives, materials and strategies. From this it 
is possible to obtain a broad knowledge of the subject studied, which allows the development of future research arising from critical evaluation and synthesis of theme analyzed evidence [9].

Thus, the data collection was conducted in August and September 2015, after had become established: research protocol composing the theme of research, objective, guiding question and use of descriptors. The descriptors used were: Family Health Strategy; Health Promotion and Health Personnel. The search process has consulted the following databases: LILACS, MEDLINE/PubMed, SciELO and Cochrane Library.

The search amounted to 17.446 articles. During this stage of the research was performed the following crossings: Family Health Strategy and Health Promotion and Health Personnel (MEDLINE/PubMed 100; SciELO 2; LILACS 13; Cochrane Library 115); Family Health Strategy and Health Promotion (MEDLINE/PubMed 570; SciELO 92; Lilacs100; CochraneLibrary 940); Health Promotion and Health Personnel (MEDLINE/ PubMed 8830; SciELO84; LILACS 118; Cochrane Library 6482), as Figure 1 below.

After the reading of the titles and abstracts, the following inclusion criteria were applied: articles available in full and free by Capes portal; productions related to the research problem; studies in the languages Portuguese, English and Spanish, no restrictions on the type of study. Moreover, the exclusion criteria used were duplicated productions, of which only one of the reps would be selected; letters to the editor; integrative reviews; dissertations and theses.

From there the articles were pre-selected and saved in the computer. Then complete reading of these studies were conducted, of which 23 articles were selected (SciELO7, LILACS 8; MEDLINE/PubMed 5, Cochrane Library 3) presenting its methodological trajectory clearly.

Finally, data were extracted by the model instrument and validated for data collection [10] and then organized into two frames, where the first of them contained: presentation of studies, references, place of study, objective, method database. The second framework was composed of the item "health promotion" after established the FHT assistance model. This framework was illustrated by counting the number of times each result appeared being grouped by similarity. These groupings emerged the potential, weaknesses and challenges. These results were presented descriptively and analyzed in the literature light.

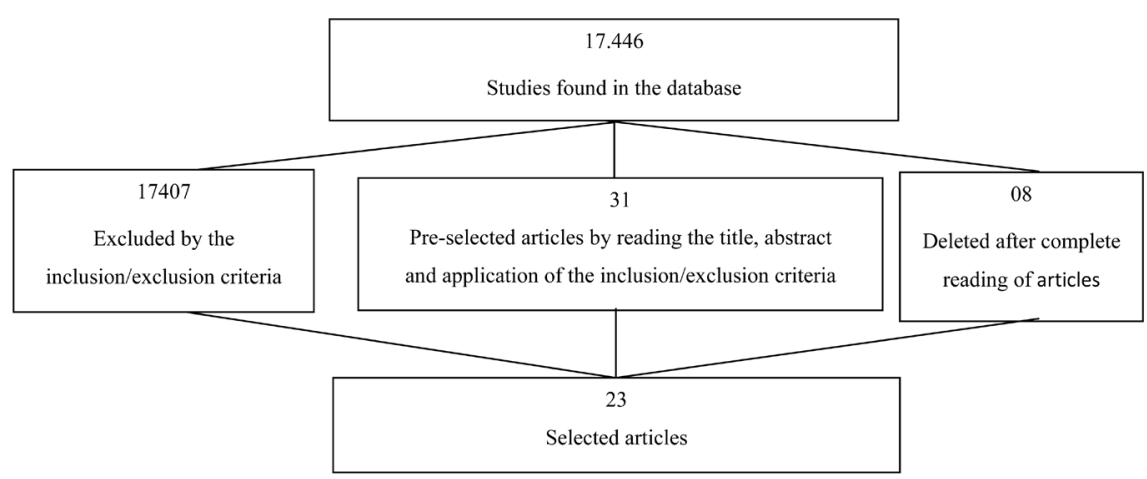

Figure 1. Flowchart of searching process. 


\section{Results}

The Table 1 presents 23 studies on health promotion established after the FHS assistance model. All the mentioned studies were developed in Brazil, the country where there is this health strategy. In addition, it was observed prevalence of qualitative method with publications beginning in 2004 .

It is observed in Table 2: potentialities, weaknesses and challenges by the situation of health promotion established after to FHS. Thus, it was appointed high- lighted the health education activities, support groups and home visits as potentialities.

However, other studies also indicate: absence or lack of health promotion activities, absence or lack of medical professional commitment in promotion activities, pro- fessional dissatisfaction, wholeness in family care neglected and presence of the curative model. So there is the challenge of professional qualification and the consolidation of the process of building of health promotion in the FHS.

\section{Discussion}

In search of better health conditions in the community's daily life, the Ministry of Health (MH) implemented in 1991 the Program of Community Health Agents (PCHA). The PCHA had primary focus for the expansion of primary care coverage and introduction of the Community Health Agent (CHA). The program was responsible for interlocution between government and community, enabling actions in the quality improvement of life and community well-being to which they belong [34] [35].

According to chronology proposed by MH, it was established in 1994 the PSF, now called the Family Health Strategy (FHS). The FHS was created to meet needs of the population, using the work of the daily epidemiological approach. In this perspective there must be understanding of the multiple risk factors to health and the possibility of intervention on them. For this are necessary different strategies, such as health promotion [35].

In order to promote better understanding it is noteworthy that the Home Visit (HV) was inserted in the health since the mid-twentieth century when there was still a curative model. However, given the changes to integral model and then FHP, the practice of HV started to work in the intervention of the health-disease process of individuals or planning actions aimed at promoting the health of the community [35].

The development of these shares is attributed to the CHA-the most prominent professional in ESF-because these professionals know the daily routine and community territoriality in which CHA is inserted. For this reason, health promotion and prevention are made possible by the agents in order to provide better health and quality of life. Therefore it is necessary that CHA guide the community and families that are under their responsibility. These actions are based on the family, territoriality and responsibility [36].

Beyond practices of prevention, DV is also responsible for health education activities, where the agent informs families about the FHP program, well-being and quality of life [35]. 
Table 1. Characterization of the studies (Natal, Brazil, 2015).

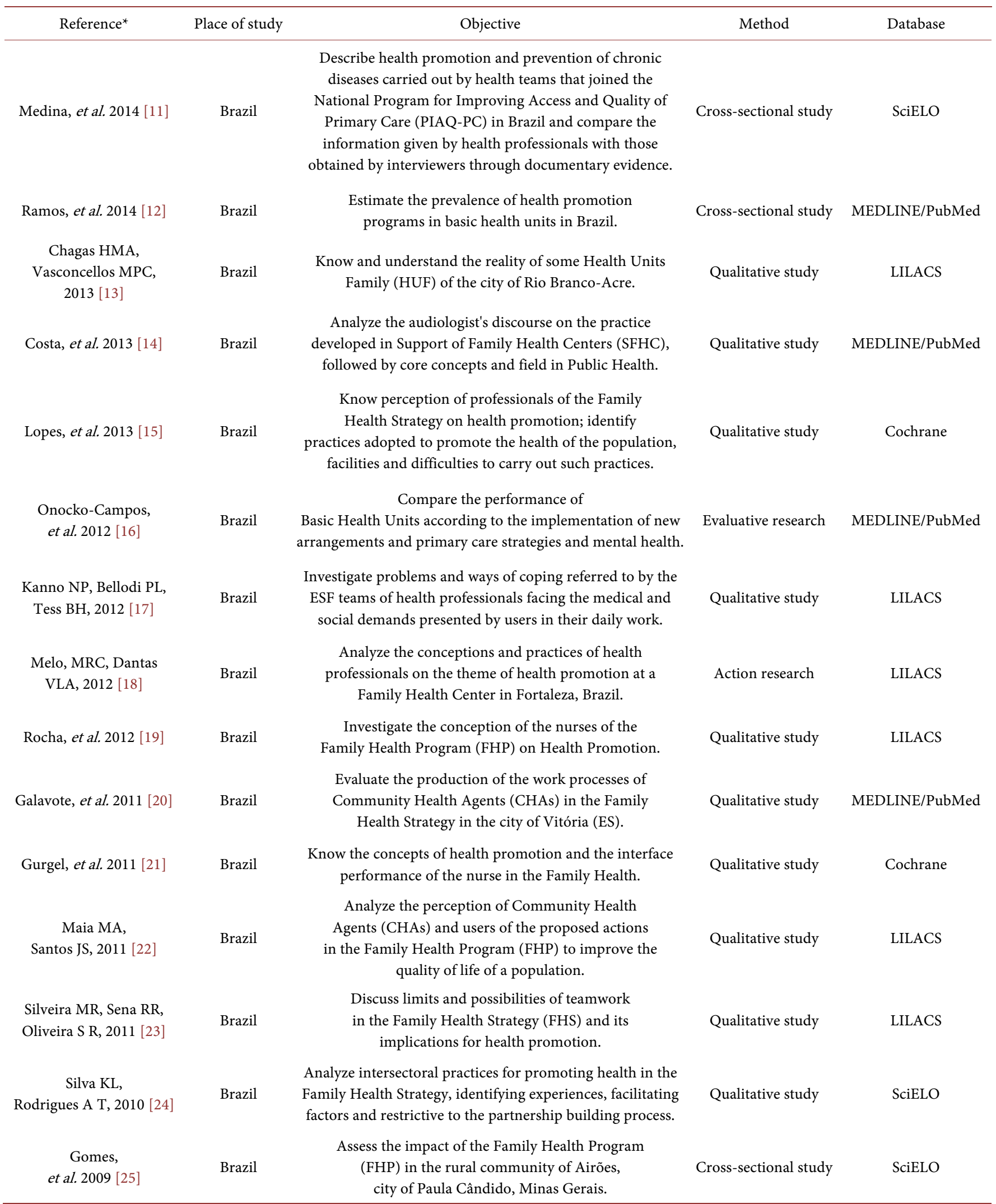




\section{Continued}

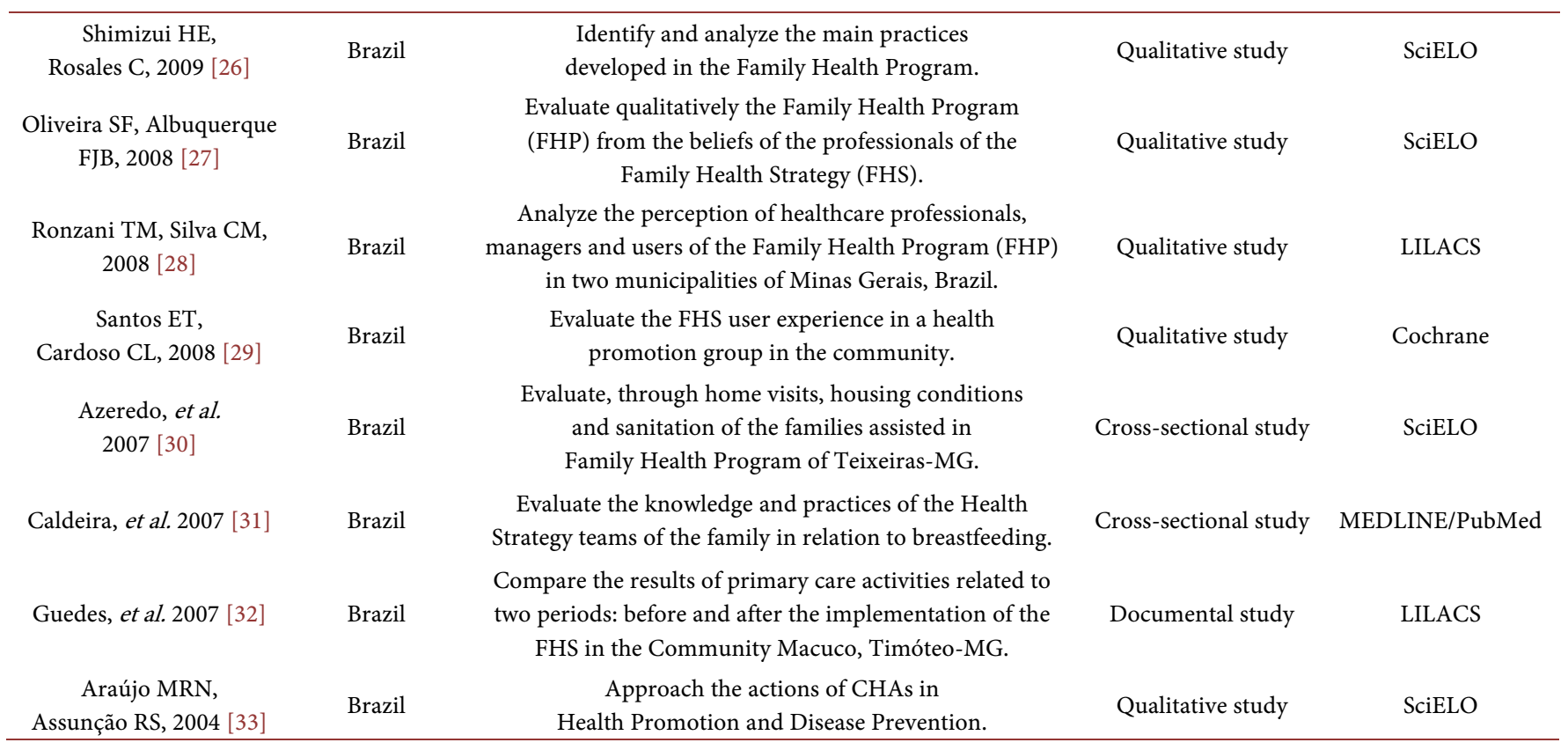

Font: research data. ${ }^{*}$ The reference column of Table 1 has superscript numbers on each line to identify of articles on column 2 of Table 2.

Table 2. Situation of health promotion established after the implementation of the Family Health Strategy Natal, Brazil, 2015.

\begin{tabular}{|c|c|}
\hline & Situation of health promotion after established the FHS \\
\hline Potencialities & $\begin{array}{ll}\text { - } & \text { Identification of the situation of population health [17] [30] } \\
\text { - } & \text { Home visits [15] [20] [22] [26] [30] [31] [32] } \\
\text { - } & \text { Health education activities [11] [12] [14] [15] [19] [25] [27] [30] [31] [33] } \\
\text { - } & \text { Support groups [13] [14] [15] [17] [19] [23] [29] } \\
\text { - } & \text { Intervention with families [21] [28] } \\
\text { - } & \text { Health Agent as a category of the most prominent teams [28] } \\
\text { - } & \text { Housing in the same work area [16] [30] } \\
\text { - } & \text { Reorientation of health services [23] } \\
\text { - } & \text { Reinforcement of community action [21] } \\
\text { - } & \text { Job integration in teams and among sectors [16] [17] [23] } \\
\text { - } & \text { Reduction of number of hospital internment [32] }\end{array}$ \\
\hline Weaknesses & $\begin{array}{ll} & \text { Integrality in family care neglected [17] [26] } \\
\text { - } & \text { inadequate infrastructure [27] [33] } \\
\text { - } & \text { Dissatisfaction of professionals [27] [28] } \\
\text { - } & \text { Unsuitable materials and equipment for use [27] } \\
\text { - } & \text { Model curative [22] [27] } \\
\text { - } & \text { Assistance focused only on the prevention [28] } \\
\text { - } & \text { The actions are still organized in a normative reference, biomedical and non-dialogical [11] } \\
\text { - } & \text { Number of home visits less than the recommended [13] } \\
\text { - } & \text { Absence or lack of medical professional commitment in the promotion activities [13] [31] } \\
\text { - } & \text { Absence or lack of health promotion activities [12] [19] [24] [28] } \\
\text { - } & \text { Absence of reorientation of health services [19] } \\
\text { - } & \text { Confusion between the concepts of promotion and prevention [18] [22] }\end{array}$ \\
\hline Challenges & $\begin{array}{l}\text { - } \quad \text { Professional qualification [25] } \\
\text { - } \quad \text { Promotion in the FHS is still a construction process [23] }\end{array}$ \\
\hline
\end{tabular}

Font: research data. 
Conversely, the FHS is one of the guiding principles of the integration of the multidisciplinary team. This team is often viewed positively among professionals involved, because they can share information, enriching the team. Thus it becomes possible to face, in addition to individual and biological health problems, collective and socio-cultural problems of individuals and the community by which the health team has sanitary responsibility [35].

In addition, the FHS has characteristics for the development of educational activities corroborating for open discussions between user and professional, built on health situations of social groups or specific classes [37] [38].

Thus, developed study reveals that such practices serve as a tool for health promotion by offering knowledge of social, political and economic determinants of the healthdisease. In health promotion the dynamics of support groups set up in the interaction between health professionals and users. Through communication and participation, both conduct dialogue on the conditions and determinant factors of health. This allows greater control of the subjects on the social and environmental context in which people are inserted [39].

Such practices are evidenced quantitatively about the impact on the rate of hospitalizations, when a study showed a relation between the gradual increase in the FHS coverage percentage and the consequent reduction in hospitalizations rates [40].

Opposed to this, health faces great problems to cater to its different current models, which propose activities of promotion, protection, recovery and rehabilitation of health. This is because there are still family health teams with curative practice, performing activities only in the presence of disease. Thus home visits targets comes to be lower than recommended by the FHS [41] [42].

The improvement and efficiency of services provided by family health teams are directly linked to infrastructure and good quality equipment. However, it is still common to find units with inadequate physical structures, sometimes even improvised besides maintaining use of obsolete equipment. Given that the FHS should solve about $85 \%$ of community health problems, it is necessary to have structural features and compatible devices that allow the action of professionals in relation to that commitment [43].

Health professionals are important stakeholders in the practice of health promotion within the family health. In this sense, the term "work environment saludable" represents a healthy workplace aiming at the welfare of professionals from: physical environment, good personal relationships, good organization and emotional health. These factors are directly related to job satisfaction [44].

However, there are often neglect these factors as their own needs. This causes low involvement of the professional towards the promotion actions and to the assisted population [45].

Health promotion activities are still very confused with preventive character. On this light, there is a common census that health teams work with an educational and preventive profile. Moreover, there is the vision of education as predominantly one-way transmission of knowledge [46]. This type of interpretation interferes with the actions to be developed for health promotion in the FHS. 
Thus, it notes that the professionals qualifications and health promotion in the FHS are challenges to be overcome and are in process of construction. Despite this, the qualification and promotion mentioned can be achieved through actions that coordinate communication between the participants through solidarity, interdisciplinary and intersectionality [47].

\section{Conclusions}

The autonomy of the people on healthy living allows them to be protagonists of their own health. This is because it is considered autonomy as great ally both in health development, and for the policies and actions recommended by the promotion within the scope of the FHS.

Thus, this study synthesizes scientific knowledge on the promotion of health after establishing the FHS assistance model, listing the potentialities, weaknesses and challenges. In this way, the selected articles showed that the multidisciplinary work of the FHS teams is the principal means for interaction of families with health actions, as the promotion practices recommended by the Strategy.

However, despite the potential, it is found that the promotion of health in the FHS process is still under construction, since there is a stagnation by some health workers regarding the act of promoting health. Moreover, many professionals are still conniving to the curative practices, even with the policies of promotion, humanization and assistance.

This situation was explained by the studies when they claim that health professionals are not motivated or do not have the professional qualification in family health area. It is further that there is deprivation and even lack of health promotion activities associated to identified weaknesses. Thus, it identifies curative practice disguised as health promotion.

Therefore, with the development of this study it is expected that the reader understands the importance of knowledge about health promotion actions as main policy within the family health. And the need for adequacy of professionals is identified regarding the current health policies, so there is reaffirmation of what really FHS recommends.

\section{References}

[1] Whorld Health Organization (WHO) (2014) Basic Documents. 48th Edition. http://apps.who.int/gb/bd/PDF/bd48/basic-documents-48th-edition-sp.pdf\#page $=7$

[2] Silva, R.P.G. and Rodrigues, R.M. (2010) Health Unic System and Course of Nursing Undergraduate in Paraná. Revista Brasileira de Enfermagem, 63, 66-72. https://doi.org/10.1590/S0034-71672010000100011

[3] WHO (1986) Carta de Ottawa.In: Ministério da Saúde/FIOCRUZ. Health Promotion: Ottawa Letters, Adelaide, Sundsvall and Santa Fé de Bogotá. Ministério da Saúde/IEC, Brasília. http://bvsms.saude.gov.br/bvs/publicacoes/carta ottawa.pdf

[4] Brasil (1990) Law No. 8080. Regulates Conditions for the Promotion, Protection and Recovery of Health, the Organization and Operation of Corresponding Services and Other 
Measures. Presidency of the Republic, Brasília.

http://www.planalto.gov.br/ccivil 03/Leis/L8080.htm

[5] Gracioto, A., et al. (2006) Group of Care Orientation for Families of Patients Dependent. Revista Brasileira de Enfermagem, 59, 105-108.

https://doi.org/10.1590/S0034-71672006000100020

[6] Brasi (2011) Letter of the 14th National Health Conference of Brazilian Society. 14th National Health Conference, National Health Council, Brasília.

http://conselho.saude.gov.br/14cns/docs/04 dez carta final.pdf

[7] Morosini, M.V.G.C. (2007) Models of Care and Family Health. Morosini, M.V.G.C. and Corbo, A.D., Org., Collection Professional Education and Teaching in Health: The Formation and Work of the Community Health Agent, EPSJV/Fiocruz, Rio de Janeiro, 240. http://www.epsjv.fiocruz.br/index.php?Area=Material\&MNU=\&Num=26\&Tipo=1.

[8] Brasil (1997) Family Health: A Strategy for Reorienting the Care Model. Ministry of Health, Department of Health Care, Health Coordination of the Community, Brasília. http://bvsms.saude.gov.br/bvs/publicacoes/cd09 16.pdf

[9] Mendes, K.D.S., Silveira, R.C.C.P. and Galvão, C.M. (2008) Integrative Review: A Research Method to Incorporate Evidence in Health and Nursing. Texto Contexto Enfermagem, 17, 4. http://www.scielo.br/scielo.php?script=sci $\operatorname{arttext\& pid=S0104-07072008000400018}$

[10] Ursi, E.S. and Galvão, C.M. (2006) Prevenção de lesões de pele no perioperatório: revisão integrativa da literatura. Revista Latino-Americana de Enfermagem, 14, 124-131. http://www.scielo.br/pdf/rlae/v14n1/v14n1a17.pdf

[11] Medina, M., et al. (2014) Health Promotion and Chronic Disease Prevention: What Are Family Health Teams Doing? Saúde Debate, 38, 69-82. http://www.scielo.br/pdf/sdeb/v38nspe/0103-1104-sdeb-38-spe-0069.pdf

[12] Ramos, L., et al. (2014) Prevalence of Health Promotion Programs in Primary Health Care Units in Brazil. Revista de Saúde Pública, 48, 837-844. https://doi.org/10.1590/s0034-8910.2014048005249

[13] Chagas, H.M.A. and Vasconcellos, M.P.C. (2013) When the Entrance Does Not Solves: Analysis of the Health Family Units in the City of Rio Branco, Acre. Saúde e Sociedade, 22, 377-388. https://doi.org/10.1590/S0104-12902013000200010

[14] Costa, L., et al. (2013) The Practice of Speech Language Pathologists at Family Health Support Centers in Municipalities of Paraíba. CoDAS, 25, 381-387. https://doi.org/10.1590/S2317-17822013000400014

[15] Lopes, M., et al. (2013) Health Promotion in the Perception of Professionals of the Family Health Strategy. Revista Rene, 14, 60-70. http://www.revistarene.ufc.br/revista/index.php/revista/article/view/1333/pdf

[16] Onocko-Campos, R., et al. (2012) Evaluation of Innovative Strategies in the Organization of Primary Health Care. Revista de Saúde Pública, 46, 43-50. https://doi.org/10.1590/S0034-89102011005000083

[17] Kanno, N.P., Bellodi, P.L. and Tess, B.H. (2012) Family Health Strategy Professionals Facing Medical Social Needs: Difficulties and Coping Strategies. Saúde Sociedade, 21, 884-894. https://doi.org/10.1590/S0104-12902012000400008

[18] Melo, M.R.C. and Dantas, V.L.A. (2012) Culture Circles and Health Promotion in the Family Health Strategy. Revista Brasileira em Promoção da Saúde, 25, 328-336. http://ojs.unifor.br/index.php/RBPS/article/view/2263/2490

[19] Rocha, P., Soares, T., Farah, B. and de Castro Friedrich, D. (2012) Health Promotion: The Design of the Nurses Who Work in the Family Health Program. Revista Brasileira em 
Promoção da Saúde, 25, 216-220. http://ojs.unifor.br/index.php/RBPS/article/view/2231

[20] Galavote, H., do Prado, T., Maciel, E. and de Cássia Duarte Lima, R. (2011) Unraveling the Community Health Agent Working Processes in the Revealed Scenarios in the Family Health Strategy in the City of Vitória (ES, Brasil). Ciência \& Saúde Coletiva, 16, 231-240. https://doi.org/10.1590/S1413-81232011000100026

[21] Gurgel, M., et al. (2011) Health Promotion in the Context of Family Health Strategy: Conceptions and Practices of Nurse. Escola Anna Nery, 15, 610-615. https://doi.org/10.1590/S1414-81452011000300024

[22] Maia, M.A. and Santos, J.S. (2011) Quality of Life in the Family Health Program: Vision of Community Health Workers and Users. Revista Brasileira Promoção da Saúde, 24, 228-237. http://ojs.unifor.br/index.php/RBPS/article/view/2076/2369

[23] Silveira, M.R., Sena, R.R. and Oliveira, S.R. (2011) Family Health Teamwork Development and Its Effectiveness on Health Promotion. Revista Mineira de Enfermagem, 15, 196-201. http://bases.bireme.br/cgi-bin/wxislind.exe/iah/online/?IsisScript=iah/iah.xis\&src=google\& $\underline{\text { base }=\text { BDENF\&lang }=p \& \text { nextAction }=\operatorname{lnk} \& \text { exprSearch }=20322 \& \text { indexSearch }=I D}$

[24] Silva, K.L. and Rodrigues, A.T. (2010) Intersectorial Actions for Health Promotion in Family Health Strategy: Experiences, Challenges, and Possibilities. Revista Brasileira de Enfermagem, 63, 762-769. https://doi.org/10.1590/S0034-71672010000500011

[25] Gomes, K., et al. (2009) Evaluation of the Impact of the Family Health Program in the Epidemiology Profile of the Rural Population of Airões, City of Paula Cândido (MG), 19922003. Ciência \& Saúde Coletiva, 14, 1473-1482. https://doi.org/10.1590/S1413-81232009000800020

[26] Shimizui, H.E. and Rosales, C. (2009) Do the Practices Developed in Family Health Program Contribute to Transform the Present Model of Health Care? Revista Brasileira de Enfermagem, 62, 424-429. http://www.redalyc.org/articulo.oa?id=267019599014

[27] Oliveira, S.F. and Albuquerque, F.J.B. (2008) Health Family Program: An Analysis from the Beliefs of Their Service Providers. Psicologia \& Sociedade, 20, 237-246. http://www.scielo.br/pdf/psoc/v20n2/a11v20n2.pdf

[28] Ronzani, T.M. and Silva, C. (2008) Brazil's Family Health Program According to Healthcare Practitioners, Managers and Users. Ciência \& Saúde Coletiva, 13, 23-34. https://doi.org/10.1590/S1413-81232008000100007

[29] Santos, E.T. and Cardoso, C.L. (2008) Experiences of Participating in a Health Promotion Group in the Family Health Strategy. Psico, 39, 410-417. http://revistaseletronicas.pucrs.br/ojs/index.php/revistapsico/article/view/3572

[30] Azeredo, C., Cotta, R., Schott, M., de Matos Maia, T. and Marques, E. (2007) Assessment of Sanitation and Housing Conditions: The Importance of Home Visits in the Context of the Health Family Program. Ciência \& Saúde Coletiva, 12, 743-753. https://doi.org/10.1590/S1413-81232007000300025

[31] Caldeira, A., de Aguiar, G., Magalhães, W. and Fagundes, G. (2007) Knowledge and Promotion Practices of Breastfeeding in Family Health Teams in Montes Claros, Minas Gerais, Brazil. Cadernos de Saúde Pública, 23, 1965-1970. https://doi.org/10.1590/S0102-311X2007000800023

[32] Guedes, S., Araújo, J., da Cunha Oliveira, C. and de Albuquerque, R. (2013) Analysis of Satisfaction of Family Health Professionals with Working Conditions. Ciência, Cuidado e Saúde, 12, 121-130. http://www.revenf.bvs.br/pdf/ccs/v12n1/16.pdf

[33] Araújo, M.R.N. and Assunção, R.S. (2014) The Role of the Community Health Worker in Health Promotion and Disease Prevention. Revista Brasileira de Enfermagem, 57, 19-25. 
https://doi.org/10.1590/S0034-71672004000100004

[34] National Policy for Primary Care (2012) Ministério da Saúde. Brasília. http://dab.saude.gov.br/portaldab/ape esf.php?conteudo=agente comunitario saude

[35] Filgueiras, A.S. and Silva, A. (2011) Community Health Agent: A New Actor on the Scene of Health in Brazil. Physis, 21, 889-915. http://www.scielo.br/pdf/physis/v21n3/08.pdf

[36] Cruz, M.M. and Bourget, M. (2010) Home Visiting in the Family Health Strategy: Investigating Families' Perceptions. Saúde e Sociedade, 19, 605-613. https://doi.org/10.1590/S0104-12902010000300012

[37] Moura, E. and Sousa, R.A. (2002) Education in Reproductive Health: Proposal or Reality of the Family Health Program ?Cadernos de Saúde Pública, 18, 1809-1811. https://doi.org/10.1590/S0102-311X2002000600038

[38] Brasil (2007) Health Education Guidelines for the Promotion of Health: Base DocumentDocument I/National Health Foundation. Funasa, Brasília. http://www.funasa.gov.br/site/wp-content/files mf/dir ed sau.pdf

[39] Horta, N., et al. (2009) The Practice Groups as Health Promotion Action in the Family Health Strategy. Revista de APS, 12, 293-301. http://aps.ufjf.emnuvens.com.br/aps/article/view/407/228

[40] Maciel, A.G., Caldeira, A.P. and Diniz, F. (2014) The Family Health Strategy Impact on the Hospital Morbidity Profile in Minas Gerais. Saúde Debate, 38, 319-330. http://www.scielo.br/pdf/sdeb/v38nspe/0103-1104-sdeb-38-spe-0319.pdf

[41] Scherer, M., Marino, S. and Ramos, F. (2005) Ruptures and Resolutions in the Health Care Model: Reflections on the Family Health Strategy Based on Kuhn's Categories. InterfaceComunicação, Saúde, Educação, 9, 53-66. https://doi.org/10.1590/S1414-32832005000100005

[42] Silva, J.M. and Caldeira, A.P. (2010) Health Care Model and Quality Indicators: Perceptions of Primary Health Care Professionals. Cadernos de Saúde Pública, 26, 1187-1193. https://doi.org/10.1590/S0102-311X2010000600012

[43] Brasil (2006) Physical Structure Manual of Basic Health Units: Family Health. Ministério da Saúde, Brasília. http://bvsms.saude.gov.br/bvs/publicacoes/manual estrutura ubs.pdf

[44] Casas, S.B. and Klijin, T.P. (2006) Health Promotion and a Healthy Workplace. Revista Latino-Americana de Enfermagem, 14, 136-141. http://www.redalyc.org/articulo.oa?id=281421858019

[45] Guedes, H., de Paula, L., Nakatani, A. and de Barros Coelho, A. (2007) Results after 5 Years of the Setting up of the Family Health Strategy in a Small Provincial Town in the State of Minas Gerais, Brazil. Revista Mineira de Enfermagem, 11, 363-368. http://www.reme.org.br/artigo/detalhes/358

[46] Tesser, C., Garcia, A., Vendruscolo, C. and Argenta, C. (2011) Family Health Strategy and Analysis of the Social Reality: Input for Policies for Promotion of Health and permanent Education. Ciência \& Saúde Coletiva, 16, 4295-4306. https://doi.org/10.1590/S1413-81232011001200002

[47] Pinto, B., Soares, D., Cecagno, D. and Muniz, R. (2012) Health Promotion and Intersectionality: A Process under Construction. Revista Mineira de Enfermagem, 16, 487-493. http://www.reme.org.br/artigo/detalhes/552 
Submit or recommend next manuscript to SCIRP and we will provide best service for you:

Accepting pre-submission inquiries through Email, Facebook, LinkedIn, Twitter, etc.

A wide selection of journals (inclusive of 9 subjects, more than 200 journals)

Providing 24-hour high-quality service

User-friendly online submission system

Fair and swift peer-review system

Efficient typesetting and proofreading procedure

Display of the result of downloads and visits, as well as the number of cited articles

Maximum dissemination of your research work

Submit your manuscript at: http://papersubmission.scirp.org/

Or contact ojn@scirp.org 